acids by easily recognisable abbreviations, as follows: $\mathrm{Gly}_{8} \mathrm{Ala}_{29} \mathrm{Val}_{21} \mathrm{Leu}_{50} \mathrm{Ileu}_{27} \mathrm{Pro}_{15} \mathrm{Phe}_{9}$ $\mathrm{CySH}_{4} \quad(\mathrm{CyS})_{8} \quad \mathrm{Met}_{8} \mathrm{Try}_{4} \mathrm{Arg}_{7} \mathrm{His}_{4} \mathrm{Lys}_{33} \mathrm{Asp}_{36}$ Glu $_{24}(\text { Glu-NH})_{32}$ Ser $_{20} \mathrm{Thr}_{21} \mathrm{Tyr}_{9} \mathrm{H}_{2} \mathrm{O}_{4}$ ! It might perhaps not unfairly be said that the chief contribution of the X-ray studies has been to demand and stimulate more accurate analyses.

With this vital question of analyses the earlier articles in the present volume are mainly concerned. The international character of the series is worthily maintained by an article on the analytical chemistry of proteins by A. J. P. Martin and R. L. M. Synge, the comprehensiveness of which can be judged from the fact that no less than 771 references to the literature are quoted. An excellent account is given not only of the straightforward chemical methods, but the newer techniques of chromatography as developed by the authors themselves (partition chromatography), by Tiselius (front analysis) and by Wieland, Turba, Block and others.

Complementary to this is an article on the microbiological assay of amino-acids by E. E. Snell. These methods equal the accuracy of the best chemical methods and seem likely to displace them for routine tests now that a considerable variety of suitable organisms is available. This article is appropriately followed by a discussion by R. J. Block of the aminoacid composition of food proteins.

S. W. Fox discusses the identification of the terminal amino-acids of peptides and proteins-perhaps the Achilles' heel of protein research, since if the termina] groups are removed one after another, or if the chain is broken in a suitable number of places and the terminal groups identified, the complete order of the amino-acids ean be arrived at in time. It is a little unfortunate that the greatest successes of this method so far, the identification of the terminal groups of insulin by Sanger and the elucidation of the order of the amino-acids in the peptide gramicidin by Synge, should have been published too late to be quoted.

The remainder of the volume is made up of a rather miscellaneous collection of articles on various topics, and the writer cannot do more than indicate their subjects. P. R. Cannon discusses antibody formation from the point of view of the amino-acid requirements involved. C. R. Dawson and M. F. Mallette give a detailed account of the copper proteins, the most interesting examples being the hæmocyanins which function in the blood of invertebrates such as crabs, snails, lobsters, etc., in much the same way as the iron protein, hæmoglobin, in the blood of animals. K. Meyer gives an account of mucoids and glycoproteins, a field which he defines as that of natural substances containing hexosamine. The proteins of this group contain such diverse and interesting substances as the gonadotropic hormones, serum albumen and globulin and egg albumen.

M. J. Blish describes the proteins of wheat gluten, their composition and properties-a matter of profound importance at a time when the most economical utilization of the wheat grain is of urgent interest to a large part of mankind. Within a few days of the start of bread rationing it is strange to read that "until recently wheat was regarded as one of the more serious surplus commodity problems", a fact which stimulated inquiry into possible non-food industrial utilizations of the wheat protein !

The remaining articles cover ground, some part of which has been reviewed in other publications not long ago. D. French and J. T. Edsall discuss at considerable length the reactions of formaldehyde with amino-acids and proteins.' M. L. Anson gives a clear and detailed picture of the difficult and complicated subject of protein denaturation.

If the editors go on like this, we shall soon have an extensive and up-to-date reference library on proteins. The two volumes which have come out have been in almost continuous use in the writer's laboratory. References to articles which are to be printed in vol. 3 have already been noted and its appearance will be awaited with impatience.

\section{J. A. V. Butler}

\section{PROGRESS IN INDUSTRIAL RESEARCH}

Industrial Research and Revellopment in the United
Kingdom A Survey. By Sir H. Finglo Heath and A. L. Hetherington. Pp. xiii $-375+23$ plates. (London : Faber and Faber, Lta., 1946.) 25s. net.

7 laympris coptehensive survey is written for the non-experts, but who had in its earlier days much adnengtrative experience in the then newly formed Dept tment of Scientific and Industrial Research. With the aid of numerous experts they trace the growth on the technical side of the major sections of British industry and very briefly describe the efforts made by co-operative research to assist many of them.

The miscalculation on the part of the Department of Scientific and Industrial Research of the time required to establish the research association move. ment as an essential part of British industry is freely admitted. On the other hand, it does not seem to be realized that during the all-out efforts of war-time, laboratory results may be developed on a large scale with little time-lag, which in peace always tends to be much longer. In a national emergency the cost factor in production is not so much emphasized, with the result that the material benefits arising immediately from research are exaggerated at the end of a great war. This belated discovery on the part of the Department of Scientific and Industrial Research proved to be a greater handicap on those research associations which with slender resources devoted themselves more to solving fundamental problems related to their industry than to obtaining immediate results on a short-term policy. The survey includes the authors' summation of the qualities required for a successful director of a large research organisation.

The often slow and tortuous history of the applications of science in Government Departments and the Services is effectively described.

On the whole, the book may be welcomed as giving an accurate picture of industrial research as it was in the early forties. It doès not, however, sufficiently impress the reader with the difficulties of developing laboratory results into large-scale practice. The workers in this immense field will all regret that the authors, with so much experience, have designedly limited themselves to a purely descriptive account of past progress; and have made little attempt to draw general conclusions or to offer advice on future action.
Robert H. Pickard 